\title{
ГОДИШНА КОНФЕРЕНЦИЯ НА СОФИЙСКОТО ОФТАЛМОЛОГИЧНО ДРУЖЕСТВО „НОВОСТИ В ОФТАЛМОЛОГИЯТА” ПРАВЕЦ 2016
}

От 2 до 4 декември 2016г. в Хотел Риу Правец се проведе годишната конференция на Софийското офталмологичнодружество - „Новости в офталмологията”.

Тези срещи, през последните години, се превърнаха в очаквано събитие за споделяне на световния и български опит, в новите тенденции за лечение на очните болести. В неформална атмосфера българските офталмолози получават години наред прекрасна възможност за представяне на най-новите постижения в световната и българската офталмологична наука и практика.

Конференцията през 2016г. се радваше на огромен интерес с 541 регистрирани участници, от които 428 офталмолози и специализанти по офталмология и 113 представители на фирми.

И тази година се проведе полудневен курс за спациализанти. Тематиката беше - Диабет и око. В изпълнената зала Проф. Михаил Боянов, от Клиниката по ендокринология на Александровска болница и водещи български офталмолози представиха най-новите тенденции за диагностика и лечение на диабета и диабетната ретинопатия.

За първи път в рамките на конференцията бе проведен и полудневен курс за медицински сестри и специалисти, който също се радваше на засилен интерес.

По традиция в рамките на конференцията „Новости в офталмологията” бе проведен конкурс за най-добър млад учен, за наградата на името на Проф. Дъбов. При засилена конкуренция и високо научно ниво на докладите, тази година наградата бе присъдена на д-р Р. Христова от Клиника по Очни болести, УМБАЛ Александровска за научна разработка на тема: „Трансплантация на ex vivo размножени лимбални стволови клетки".

Традиционно и тази година бяха удостоени и трите най-инересни електрони постера.

За първи път Софийското офталмологично дружество учреди и присъди награди за най-добра снимка с история, направена чрез смартфон. Бяха врьчени две награди: награда на журито - таблет и награда на публиката - лупа за офталмобиомикроскопия.

През последния ден на конференцията бяха организирани две кръгли маси по теми на актуални иновативни методи за диагностика и лечение. Първата кръгла маса: „Нови технологии в катаракталната хирургия. Премиум лещи” възбуди интересен дебат относно фемтосекундната лазерна хирургия и подбора на високотехнологични премиум лещи.

Втората крьгла маса, с която завърши конференциата бе на тема: „Флуоресцеинова ангиография, ОСТ и ОСТ-ангиография в сьвременната диагностика на заболяванията на ретината”. В рамките на тази кръгла маса бяха представени и дискутирани възможностите за иновативна неинвазивна диагностика, чрез ОСТ-ангиография в сравнение с класическите флуоресцаинова ангиография и оптична кохерентна томография.

На „Новости в офталмологията” не липсваха и чуждестранни лектори. Проф. Стефан Турау от Германия представи обстоен доклад върху нови диагностични и терапевтични концепции при лечението на увеитите, а Проф. Бора Елдем от Турция говори за индикациите за приложение на съвременните медикаменти за лечение на дегенерация на макулата.

Както винаги, време остана и за социални контакти, и изпълнена с настроение гала вечер. 